\title{
Alkaline activation of cement pastes with desulfurization slag
}

\author{
H.N.Costal*, C.C.Noberto ${ }^{2}$, L.A.Almeida' ${ }^{2}$ R. E. F. Q. Nogueira, A. E. B. Cabral \\ ${ }^{1}$ Universidade Federal do Ceará, Programa de Pós-Graduação em Engenharia e Ciência de Materiais, \\ Fortaleza, CE, Brazil \\ ${ }^{2}$ Universidade Federal do Ceará, Programa de Pós-Graduação em Estruturas e Construção Civil, \\ Fortaleza, CE, Brazil
}

\begin{abstract}
The capability to recycle waste materials, such as steel slag, has appealed to the construction industry, as the cement industry faces a major challenge to reduce carbon dioxide $\left(\mathrm{CO}_{2}\right)$ emissions into the atmosphere. This paper investigated the obtainment of cement pastes with Kanbara reactor desulfurization waste slag (KR slag) through alkaline activation using silicate and sodium hydroxide solutions. The mixtures were analyzed by X-ray diffraction (XRD), Fourier transform infrared spectroscopy (FTIR), thermogravimetric analysis (TGA), differential scanning calorimetry (DSC), compressive strength, and physical property tests. The FTIR, XRD, and TGA results pointed to chemical activation, forming C-S-H and C-(A)-S-H gels. The formation of these compounds indicated the possibility of using KR slag in cementitious composites for civil construction.
\end{abstract}

Keywords: cementitious paste, specific residue, chemical activation.

\section{INTRODUCTION}

The main reason for researching and developing alkaliactivated materials is the potential reduction in $\mathrm{CO}_{2}$ emissions by using industrial waste found in some regions. Each ton of Portland cement generates around $640 \mathrm{~kg}$ of $\mathrm{CO}_{2}$, whereas little or no environmental footprint is attributed to alkali-activated materials obtained from waste [1], thus providing a remarkable saving of greenhouse gas emissions [2]. According to the RILEM Technical Committee 224-AAM [3], alkali-activated materials are classified into two groups based on the activation and the chemical nature of the phases formed. Group one has systems containing precursors with high calcium content and is particularly formed by metallurgical slags. Group two has systems formed by precursors with low calcium content and is predominantly formed by aluminosilicates (metakaolin and fly ash). This group includes materials known worldwide as geopolymers. Moreover, sodium and potassium hydroxides and silicates are generally used to promote alkaline activation.

In group one, the use of ground granulated blast-furnace slag (GGBS) prevails. Since 1940, several studies have been carried out mainly to understand the chemical reactions and the nature of the phases formed in the alkali-activation process [4]. GGBS is obtained from pig iron and is widely described as a mixture of low crystalline phases containing oxides of calcium, aluminum, silicon, and magnesium. GGBS is commonly used as supplementary material for Portland cement due to its reasonably consistent physical and chemical characteristics, as long as it receives great quality control during its production [5]. Therefore, in many regions, GGBS is destined for the cement industry, which prevents its use in alkali-activated

*heloina@ufc.br

Dhttps://orcid.org/0000-0001-9960-2383 materials. However, in the steelmaking process, other types of slag are generated, such as steel slag (obtained from converting iron to steel), with compositions depending on both the production process and the degree to which recycled materials are incorporated. These slags have more variants in terms of chemical composition, which are influenced by the industrial plants and the different batches formed in the process within the same plant. The main types of steel slag include electric arc furnace slag (EAFS), basic oxygen furnace slag (BOFS), ladle slag (LS), and Kanbara reactor desulfurization waste slag (KR slag) [6]. The KR slag is generated during the preliminary treatment of cast iron. Briefly, even a small amount of sulfur mixed with steel decreases the quality of the final product. For this reason, cast iron manufactured in a blast furnace (BF) undergoes a desulfurization process to eliminate sulfur, which can be present in the range of $1 \%$ to $3 \%$ of the total mass. The agitation of the Kanbara reactor is the representative process of desulfurization. In the KR slag process, a mechanical stirring is performed after the supply of calcium oxide $(\mathrm{CaO})$. Then, the sulfur present in cast iron reacts with $\mathrm{CaO}$ forming calcium sulfide $(\mathrm{CaS}) . \mathrm{CaS}$ and unreacted $\mathrm{CaO}$ rise to the surface of the cast iron due to their low specific masses and become slag [7].

The steel slag generated in Brazilian steelmakers has a sales rate of just $37 \%$ and internal use of $26 \%$ [8]. In the State of Ceará, Brazil, the Pecém Steel Company (CSP) generates around $300 \mathrm{~kg}$ of $\mathrm{BF}$ slag for each ton of pig iron. The refining stage generates about 100 to $150 \mathrm{~kg}$ of steel slag for each ton of liquid steel processed [9]. BF slag is used by the local cement industry; however, steel slag recycling is not common, resulting in waste accumulation and, consequently, environmental liability. The focus of this study is to evaluate the alkaline activation in KR steel slag. So, we produced cementitious pastes with solutions of silicate and sodium hydroxide and carried out microstructural and mechanical analyses. 


\section{MATERIALS AND METHODS}

Materials: the KR slag used was from the Pecém Steel Co. (CSP), located in Ceará, Brazil. The residues received treatment to adjust granulometry, first using a jaw crusher, followed by a ball mill for $12 \mathrm{~h}$ and sifting through a sieve with a $150 \mu \mathrm{m}$ opening. Then, the quantification of the chemical components was performed by X-ray fluorescence spectroscopy (Table I). The slag specific gravity was measured according to NBR 16605 standard [10], recording an average of $3.19 \mathrm{~g} / \mathrm{cm}^{3}$. A particle size distribution analysis by laser diffraction was also performed (Fig. 1). The average particle diameter was $70.6 \mu \mathrm{m}$ and the maximum diameter was $159.9 \mu \mathrm{m}$. The specific surface area was $9690 \mathrm{~cm}^{2} / \mathrm{g}$. A composition of sodium silicate and sodium hydroxide was used as an activating solution, which is considered efficient for alkaline activation of precursors of high and low calcium content. Sodium hydroxide acts as the main activator (reaction catalyst), while sodium silicate acts as an auxiliary activator and provides soluble silica to the system [11]. The sodium silicate (Kalim Quím.) had a composition with $15.08 \% \mathrm{Na}_{2} \mathrm{O}$, $32.69 \% \mathrm{SiO}_{2}$, and $52.23 \% \mathrm{H}_{2} \mathrm{O}$, and its specific mass was $1.57 \mathrm{~g} / \mathrm{cm}^{3}$. The sodium hydroxide solution was prepared with distilled water, using $97 \%$ of pure micro-pearls, $12 \mathrm{~mol} / \mathrm{L}$ of molar concentration (35.6\% of $\mathrm{Na}_{2} \mathrm{O}$ and $64.5 \%$ of $\mathrm{H}_{2} \mathrm{O}$ ), and specific gravity of $1.35 \mathrm{~g} / \mathrm{cm}^{3}$.

Table I - Chemical composition (wt\%) of KR slag.

\begin{tabular}{ccccccccc}
\hline $\mathrm{SiO}_{2}$ & $\mathrm{Al}_{2} \mathrm{O}_{3}$ & $\mathrm{CaO}$ & $\mathrm{Fe}_{2} \mathrm{O}_{3}$ & $\mathrm{MnO}$ & $\mathrm{MgO}$ & $\mathrm{SO}_{3}$ & $\mathrm{~K}_{2} \mathrm{O}$ & Others \\
\hline 8.5 & 1.7 & 54.0 & 25.7 & 3.3 & 1.6 & 3.6 & 0.4 & 0.2 \\
\hline
\end{tabular}

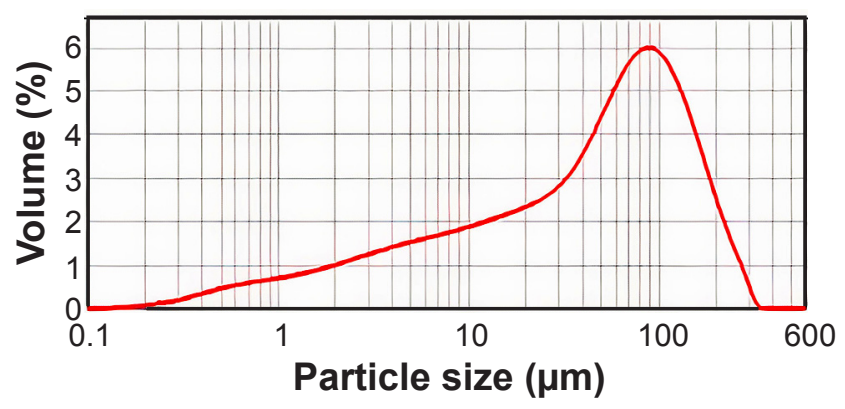

Figure 1: Particle size distribution curve of KR slag.

Methods: the variable mixing parameters were the alkaline solution/binder ratio (s/b), and the sodium silicate/ sodium hydroxide ratio (SS/SH), as shown in Table II. The parameters were the molar concentration of the sodium hydroxide solution $(12 \mathrm{~mol} / \mathrm{L})$, slag consumption (450 $\mathrm{kg} / \mathrm{m}^{3}$ ), and the additional water/binder ratio (0.2). These parameters are considered the main controllable factors influencing the compressive strength and workability of alkali-activated mixtures when there is no adjustment of molar fractions in the oxides present [12-17]. The mixture was prepared in a pan-type mixer with planetary motion used for mortars. In the first $90 \mathrm{~s}$, the mixture followed these parameters: rotation of $140 \pm 5 \mathrm{rpm}$ around the axis and
Table II - Variable factors of the mixtures tested.

\begin{tabular}{ccc}
\hline Identification & $\mathrm{SS} / \mathrm{SH}$ & $\mathrm{s} / \mathrm{b}$ \\
\hline M1 & 1.0 & 0.1 \\
M2 & 1.0 & 0.2 \\
M3 & 1.5 & 0.1 \\
M4 & 1.5 & 0.2 \\
M5 & 0.5 & 0.1 \\
M6 & 0.5 & 0.2 \\
\hline
\end{tabular}

SS: sodium silicate; SH: sodium hydroxide; s: alkaline solution; $b$ : binder.

planetary motion of $62 \pm 5 \mathrm{rpm}$. After resting for $60 \mathrm{~s}$, the parameters were adjusted to $285 \pm 10 \mathrm{rpm}$ around the axis and planetary motion of $125 \pm 10 \mathrm{rpm}$; the motion continued for another $90 \mathrm{~s}$. Then, the cubic specimens $(40 \times 40 \times 40 \mathrm{~mm})$ were molded and placed in an oven at $60^{\circ} \mathrm{C}$ for $24 \mathrm{~h}$. They were protected by a polyester film to prevent excessive loss of water by evaporation. Thermal curing (between 60 and $100{ }^{\circ} \mathrm{C}$ for 24 to $48 \mathrm{~h}$ ) is recommended in the literature for favoring the chemical reaction, especially in less reactive precursors, and for strength gain $[14,18]$. After the thermal curing process, the specimens were maintained at room temperature $\left(25 \pm 3{ }^{\circ} \mathrm{C}\right)$ until the date of tests. The M5 mixture presented fragility when demolded, being discarded in the following steps.

The mechanical performance evaluation was carried out through a compressive strength test. The adopted specimens' dimensions and quantities are commonly used in studies of alkali-activated materials [19-22]. The compression rupture occurred at the ages of 1 and 28 days, with 3 specimens tested per age. The test was carried out with a universal testing machine (DL, Emic) with a capacity of $300 \mathrm{kN}$ and a load application speed of $500 \mathrm{~N} / \mathrm{s}$. The choice of the compression rupture ages considered RILEM TC 224-AAM recommendations [3], which suggests similar procedures to those performed in the Portland cement composites since there are no specific standards for alkali-activated materials to date. At 28 days, the procedures to obtain physical indices of specific gravity, water absorption, and void content were also performed in the cubic specimens, following adapted procedures from the NBR 9778 standard [23]. The preparation of samples for microstructural analyses was done initially by fragmentation and grinding the specimens. Afterward, the samples were ground and subjected to hydration interruption [24], where they remained immersed in acetone RG for $2 \mathrm{~h}$. Then, they were placed in a Buchner filter coupled to a vacuum pump for the suction of the acetone and dried at a controlled temperature of $40{ }^{\circ} \mathrm{C}$ for 24 h. Powdered samples were characterized via Fourier transform infrared spectroscopy (FTIR), thermogravimetric analysis (TGA), exploratory differential calorimetry (DSC), and X-ray diffraction (XRD): i) FTIR is effective to determine functional groups and for studies of the structure and conformation of compounds; in this research, it was used to identify functional groups relevant to the products of the alkaline activation reaction, mainly the ones linked 
to the amorphous or semi-crystalline gels possibly formed; the analysis was performed in the attenuated total reflection mode (ATR) with the mixture of $1 \mathrm{mg}$ of powder sample in $100 \mathrm{mg}$ of $\mathrm{KBr}$ (potassium bromide), spectral analysis ranging from 1800 to $500 \mathrm{~cm}^{-1}$ with a resolution of $4 \mathrm{~cm}^{-1}$ using a spectrometer (FTIR-8300, Shimadzu); ii) TGA was used to identify the characteristic decomposition patterns of the material, while the DSC was used to measure the energy changes in cases of temperature variation, which allows characterizing the material's transition processes; in this study, the analysis of mass-loss rates and energy variation rates aimed to identify reaction products through decomposition patterns; the analyses were performed using a thermal analyzer (STA449F3A-1067-M, Netzsch) in the range from 30 to $1000{ }^{\circ} \mathrm{C}$, with a heating rate of $10{ }^{\circ} \mathrm{C} / \mathrm{min}$ and synthetic air atmosphere; iii) XRD allows the identification of crystalline compounds formed during chemical activation or the ones that did not react during the process; the analysis was performed using a diffractometer (X'Pert, PANalytical) with $\mathrm{CoK} \alpha$ radiation with an angular $2 \theta$ interval between $20^{\circ}$ and $100^{\circ}$.

\section{RESULTS AND DISCUSSION}

Compressive strength and physical properties: cement pastes showed compressive strength values between 1.5 and 6.53 MPa (Fig. 2). In general, the increase in the

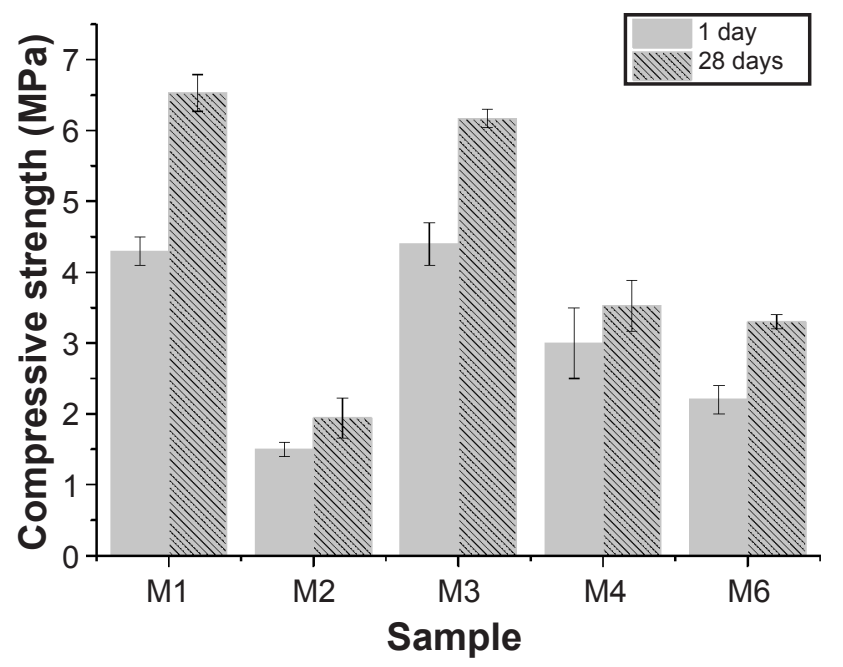

Figure 2: Compressive strength of cement pastes. alkaline solution/cement $(\mathrm{s} / \mathrm{b})$ ratio from 0.1 (in samples M1 and M3) to 0.2 (in samples M2 and M4) represented a reduction in the compressive strength, regardless of sodium silicate/sodium hydroxide (SS/SH) ratio. Among the samples with the SS/SH ratio of 1, there was a marked reduction in the strength of the $\mathrm{M} 2$ sample, reaching 70.3\% at 28 days compared to the M1 sample. Among all samples with the SS/SH ratio of 1.5 , strength decreased in the M4 sample, reaching around $42.7 \%$ at 28 days compared to M3. We could not compare samples with the SS/SH ratio of 0.5 since the M5 sample disintegrated when demolded, showing low cementing potential. The $\mathrm{s} / \mathrm{b}$ ratio of 0.1 revealed the best results for SS/SH ratios of 1 and 1.5, confirming that the $s / b$ ratio is one of the main parameters that affect the compressive strength of alkali-activated mixtures [16]. The $\mathrm{s} / \mathrm{b}$ ratio increase leads to a strength decrease due to water increasing in the mixture coming from the solution. This interferes negatively with the chemical reaction. Thus, the $\mathrm{s} / \mathrm{b}$ ratio was the most influential factor in compressive strength over the investigated mixtures [16, 25].

The results of water absorption, void content, and specific gravity of the hardened pastes are shown in Fig. 3. The higher numbers of alkaline $\mathrm{s} / \mathrm{b}$ ratio of the M2 and M4 samples are related to their higher water absorption values (Fig. 3a) and void contents (Fig. 3b) compared to M1 and M3 samples. This is the opposite result to the compressive strength analysis since the M2 and M4 samples had lower strengths than M1 and M3 (Fig. 3). There was also a decrease in specific gravity in M2 and M4 samples compared to M1 and M3. In general, the low strength obtained in the samples was related to high porosity in mixtures, which ranged from $35 \%$ to $43 \%$. Considering the void content in the samples, water absorption was rather low, varying from $18 \%$ to $28 \%$. This was probably because voids were not connected; therefore, there was no formation of capillary networks. The specific gravity of the mixtures varied between 1.54 and $1.94 \mathrm{~g} / \mathrm{cm}^{3}$. The M2 and M4 samples (whose $\mathrm{s} / \mathrm{b}$ ratio was 0.2 ) showed a lower specific mass compared to M1 and M3 $(\mathrm{s} / \mathrm{b}$ ratio of 0.1$)$.

Thermal analysis: overall, the cement pastes showed an initial drop in mass up to $100{ }^{\circ} \mathrm{C}$ in the TGA curve. At this temperature range, there was also an endothermic peak in the DSC curve, which indicated a loss of water $\left(\mathrm{H}_{2} \mathrm{O}\right)$, as shown in Fig. 4. There were endothermic peaks between 100
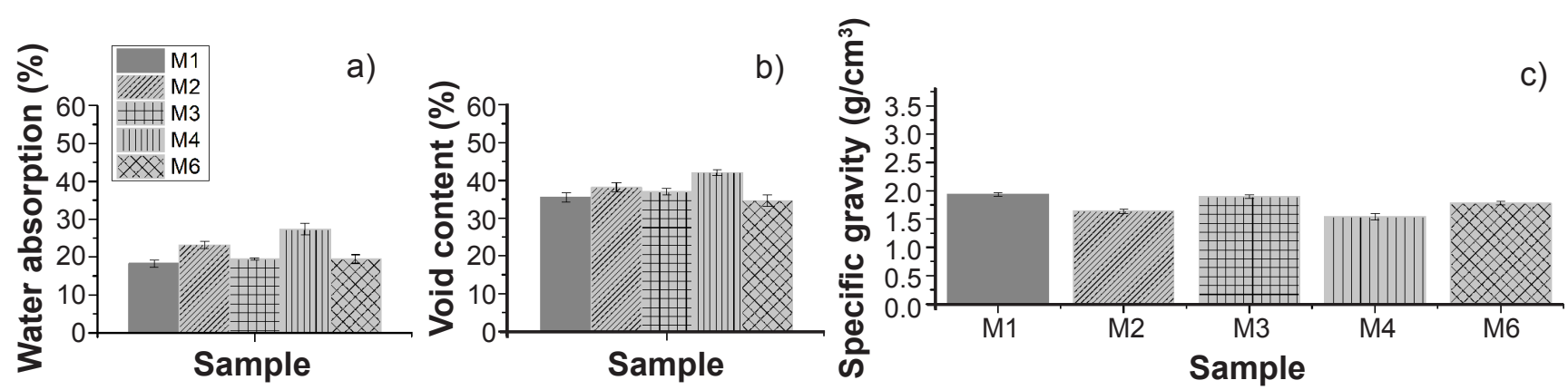

Figure 3: Water absorption (a), void content (b), and specific gravity (c) of cement pastes. 

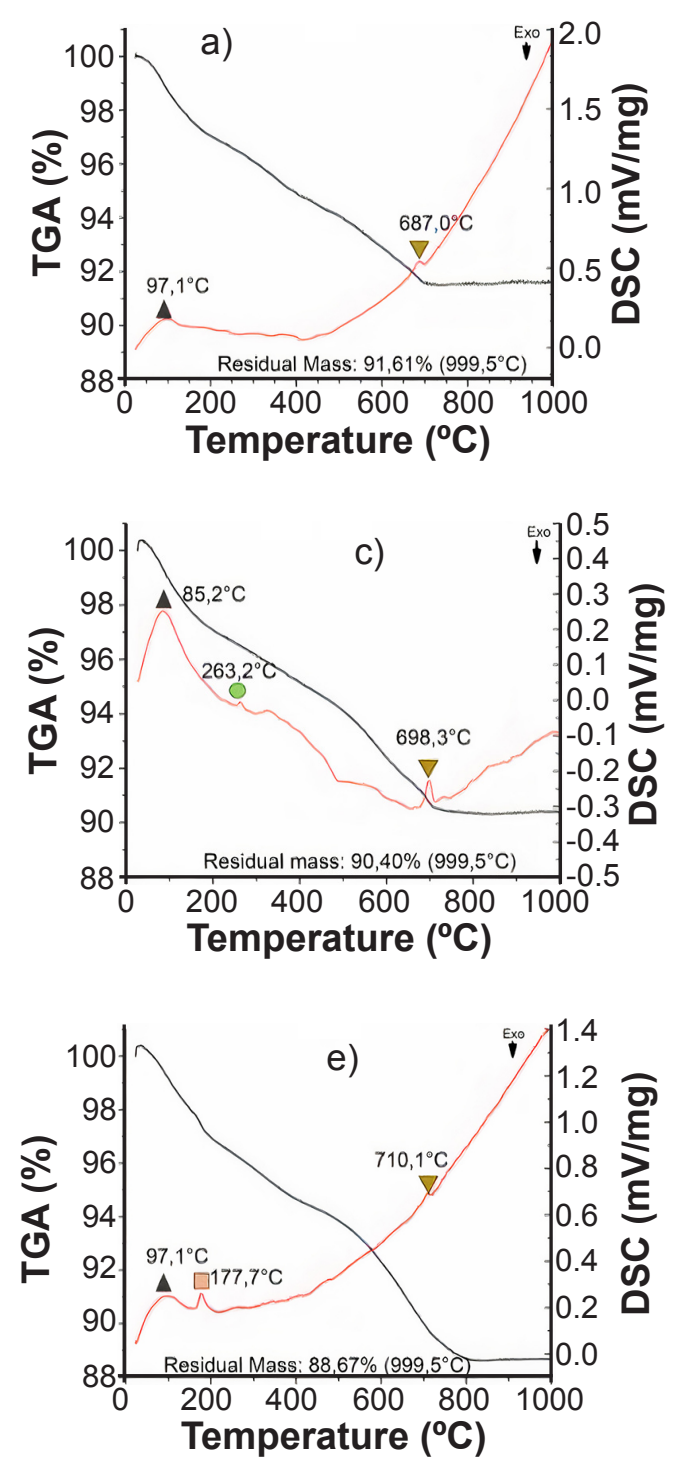
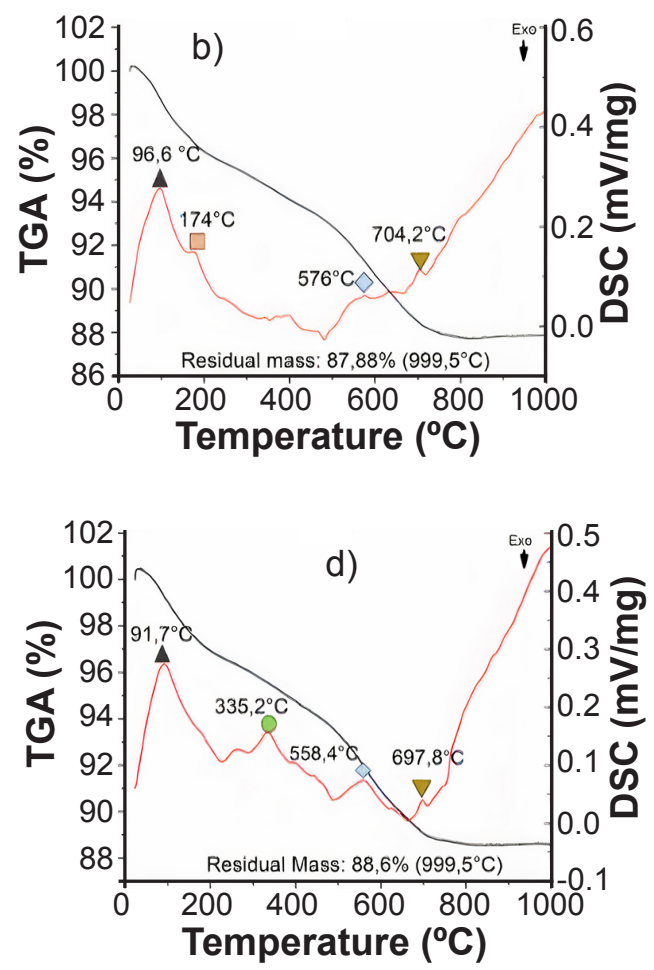

Figure 4: TGA and DSC curves of mixtures M1 (a), M2 (b), M3 (c), M4 (d), and M6 (e).

and $200{ }^{\circ} \mathrm{C}$ in M2 (Fig. 4b) and M6 (Fig. 4e). According to the literature $[26,27]$, these peaks can be attributed to the presence of semi-crystalline C-S-H gel $\left(\mathrm{Ca}_{2} \mathrm{SiO}_{4} \cdot \mathrm{H}_{2} \mathrm{O}\right)$. M3, M4, and M6 showed endothermic peaks between 200 and 400 ${ }^{\circ} \mathrm{C}$, which may be associated with loss of mass (dehydration) of the hydrotalcite phase $\left[\mathrm{Mg}_{6} \mathrm{Al}_{2}(\mathrm{OH})_{16}\left(\mathrm{CO}_{3}\right) \cdot 4 \mathrm{H}_{2} \mathrm{O}\right][26,27]$. The loss of mass seen between 400 and $600{ }^{\circ} \mathrm{C}$ is generally attributed to dehydration of the $\mathrm{C}-(\mathrm{A})-\mathrm{S}-\mathrm{H}$ phase [calcium (alumino)silicate hydrate], that is, the main reaction product of alkali-activated slags [28-30]. In all pastes, there were endothermic peaks between 600 and $800{ }^{\circ} \mathrm{C}$, indicating calcite decomposition $\left(\mathrm{CaCO}_{3}\right)$ [31]. All pastes were stable above $850{ }^{\circ} \mathrm{C}$. The highest rates of loss of mass were registered in M2 (12.12\%), M4 (11.40\%), and M6 (11.33\%) pastes. These values were related to the higher water content of the pastes since their $\mathrm{s} / \mathrm{b}$ ratio was 0.2 . So, the higher the loss of mass the higher the loss of water from the paste. In general, the loss of mass in the mixtures was between $8.39 \%$ and $12.12 \%$. The low loss of mass suggested that small amounts of products were formed by chemical reactions [22]. Normally, those amorphous or semi-crystalline gels generated in the reaction fill the solid internal voids. However, since those products were sufficient only to fill a small percentage of the void, this could explain the low compressive strengths obtained in Fig. 2 and the high void contents present in the pastes in Fig. 3.

Fourier transform infrared spectroscopy (FTIR): the main infrared absorption bands of the alkali-activated pastes (Fig. 5) were related to the formation of C-(A)-S-H or C-S-H gels. The products formed in the alkaline activation of slag with sodium hydroxide and sodium silicate solutions are, commonly, the C-(A)-S-H gel and the hydrotalcite phase coexisting with C-S-H (depending on the content of magnesium oxide present in the slag) $[26,32]$. For the calcium silicate hydrate (C-S-H) system, $\mathrm{Si}-\mathrm{O}-\mathrm{Si}$ stretch bands are commonly seen in FTIR spectra within the 950 and $1010 \mathrm{~cm}^{-1}$ wavenumber range (Fig. 5, band 3), as it is expected for C-S-H gel obtained in the hydration of Portland 
cement $[32,33]$. In the C-(A)-S-H gel formation, bands were registered between 800 to $1200 \mathrm{~cm}^{-1}$ [14]. The band associated with Si-O or Al-O stretching vibrations in the C-S-H and C-(A)-

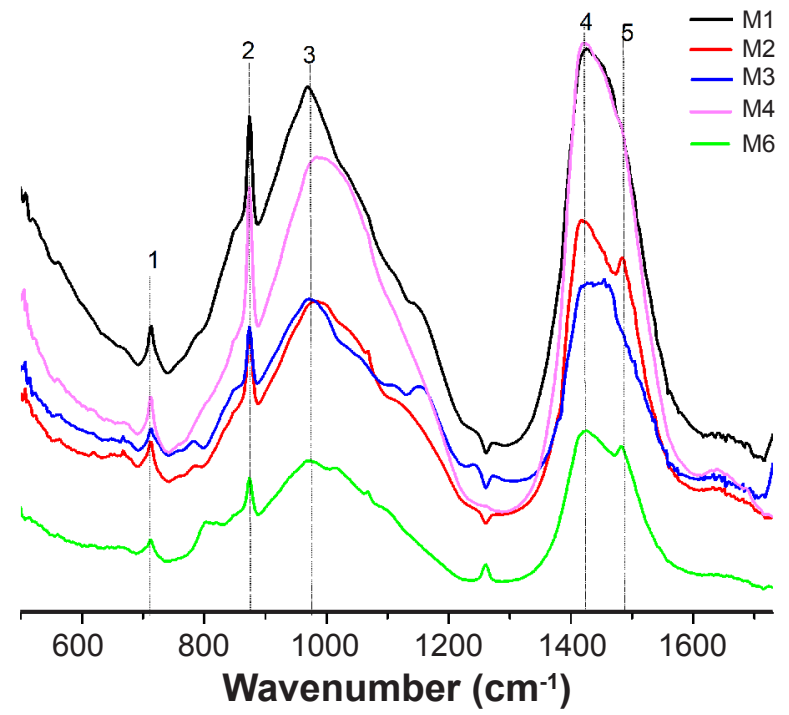

Figure 5: FTIR spectra of cement pastes.
S-H systems changed to lower wavenumbers with an increase in the $\mathrm{Ca} / \mathrm{Si}$ ratio, indicating progressive depolymerization of silicate chains [34]. Bands between 843.17 and $970.46 \mathrm{~cm}^{-1}$, which show asymmetric stretching vibrations of the tetrahedral silica $\left(\mathrm{SiO}_{4}\right)$ and vibrations of the $\mathrm{Al}-\mathrm{O}$ bonds at $707.73 \mathrm{~cm}^{-1}$, were described by Aziz et al. [33], close to what was observed in Fig. 5 (band 1). The higher peaks 1 and 3 in M1 and M4 (Fig. 5) may be associated with a higher degree of compound polymerization in these samples [35]. Peaks between 1670 and $1600 \mathrm{~cm}^{-1}$ (Fig. 5, band 4) represent vibrations of the O-H group of water molecules [14]. According to Vargas [36], the band around $1650 \mathrm{~cm}^{-1}$ is related to angular deformations of the H-O-H connection. Peak 4 (Fig. 5) may be associated with such vibrations; however, particularly in M1 and M4, it indicated greater incorporation of water in their structures. Bands of the $\mathrm{CaCO}_{3}$ group were observed at 1413, 1420, 1465, and 1490 $\mathrm{cm}^{-1}$ (Fig. 5, band 5), indicating the asymmetric stretch mode of $\left[\mathrm{CO}_{3}\right]^{2-}[14,32,37]$. Bands were also observed at $713,714,870$, 875 , and $897 \mathrm{~cm}^{-1}$ (band 2) [14,37, 38].

$X$-ray diffraction: the main crystalline compounds identified in the alkali-activated pastes were calcium carbonate, calcium hydroxide, calcium silicate, and iron
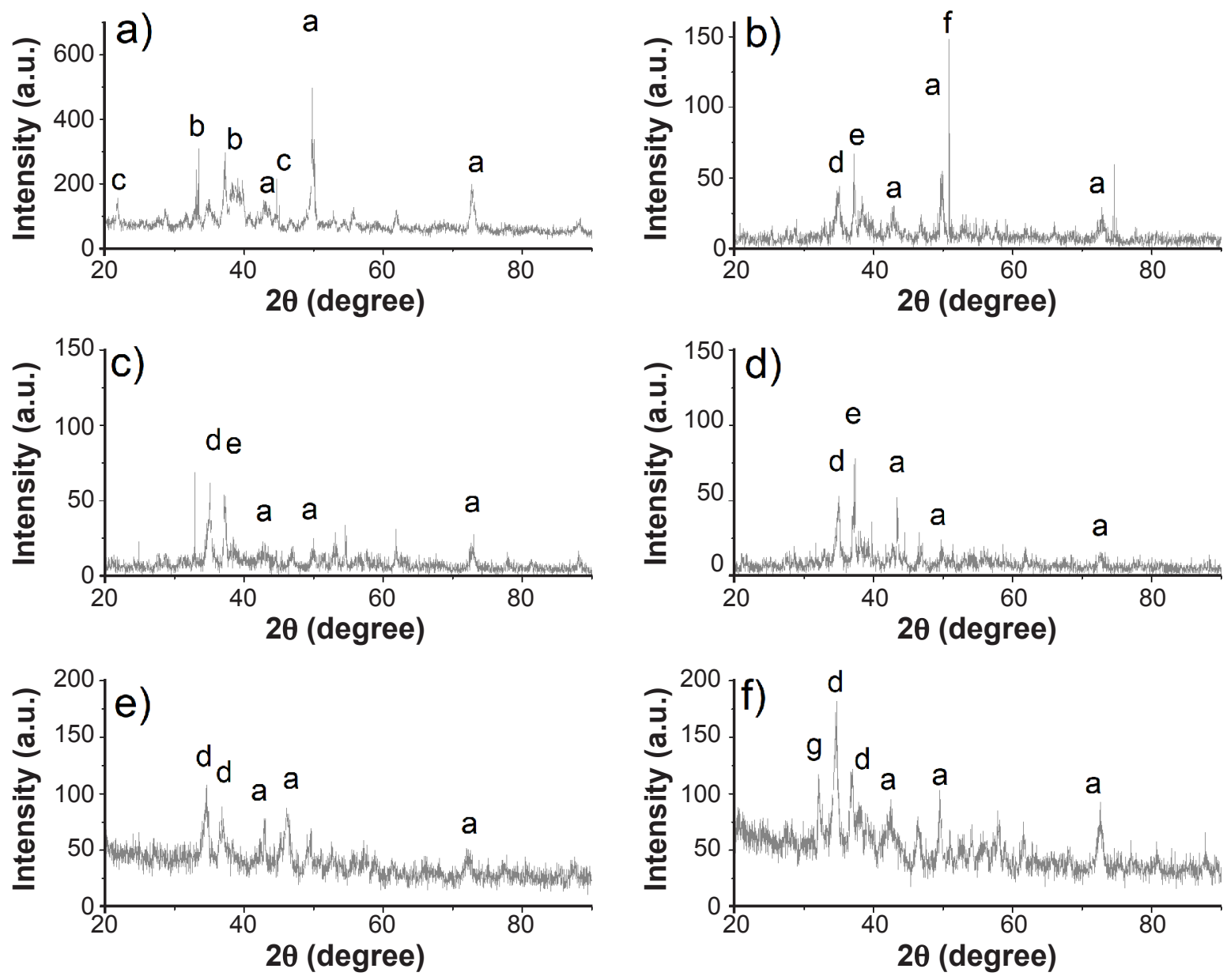

a.FeO; b. AlCaFeOMgSiO; c. MnMgSiO; d. $\mathrm{CaCO}_{3}$; e. $\mathrm{Ca}(\mathrm{OH})_{2}$; f. $\mathrm{Fe}_{2} \mathrm{MgO}_{4}$ : g. $\mathrm{CaSiO}_{3}$

Figure 6: X-ray diffractograms of KR slag (a) and pastes M1 (b), M2 (c), M3 (d), M4 (e), and M6 (f). 
oxide, as shown in the $\mathrm{X}$-ray diffractograms in Fig. 6.Calcium hydroxide $\left[\mathrm{Ca}(\mathrm{OH})_{2}\right]$ was identified in $\mathrm{M} 1, \mathrm{M} 2$, and $\mathrm{M} 3$ (Figs. 6b, 6c, and 6d, respectively). This phase is the result of the hydration of calcium oxide $(\mathrm{CaO})$ in metallurgical slags. This was also observed by Liu et al. [14], who registered the replacement of $\mathrm{CaO}$ peaks by $\mathrm{Ca}(\mathrm{OH})_{2}$ peaks during the alkaline slag activation process using sodium silicate and sodium hydroxide. The presence of $\mathrm{CaCO}_{3}$, identified in all pastes, suggested the surface carbonation of samples during the curing period since there were no $\mathrm{CaCO}_{3}$ peaks in the non-activated KR slag (Fig. 6a). When $\mathrm{CaCO}_{3}$ peaks were recorded in the diffractograms, both the anhydrous slag and the alkali-activated slag were characterized as unreacted material during the alkaline activation process [30]. The calcium silicate phase present in M6 (Fig. 6f) can be considered slag residues (i.e. unreacted product). These types of phases were identified by Cho and Choi [7], who used BF slag, KR slag, and plaster. Samples M1, M2, M3, $\mathrm{M} 4$, and $\mathrm{M} 6$ also showed peaks of wüstite $(\mathrm{FeO})$, and sample M1 showed a characteristic peak of iron magnesium oxide $\left(\mathrm{Fe}_{2} \mathrm{MgO}_{4}\right.$ ), also present in the non-activated KR slag (Fig. 6a). According to Lothenbach and Gruskovnjak [30], after alkaline activation, the intensity of peaks may vary. This was verified in alkali-activated mixtures, according to Figs. $6 \mathrm{~b}$ to 6f, which show less intense peaks compared to the KR slag graph in Fig. 6a. This pattern was due to the chemical reaction and the formation of new products. The presence of amorphous halo is also common since products of the alkaline reaction have structures ranging from amorphous to semi-crystalline [1].

\section{CONCLUSIONS}

Alkaline activation of Kanbara reactor desulfurization waste slag (KR slag) was investigated by XRD, FTIR, TGA, DSC, compressive strength, and physical property tests. The main results obtained were: i) the alkaline solution/ binder ratio $(\mathrm{s} / \mathrm{b})$ was the factor that most influenced the properties in the hardened state; as this ratio increased, there was also an increase in the total amount of water in the mixtures, which increased water absorption and void content; all these factors influenced the mechanical strength of these materials; ii) thermal analysis showed low mass-loss rates attributed to water evaporation in the composition; it indicated the formation of small amounts of products during the chemical reaction, influencing compressive strength and porosity values; these properties were improved with paste densification, which increased with the presence of $\mathrm{C}-\mathrm{S}-\mathrm{H}$ and $\mathrm{C}-(\mathrm{A})-\mathrm{S}-\mathrm{H}$ gels; iii) the presence of semi-crystalline C-S-H gel, C-(A)-S-H gel, and hydrotalcite was observed in the results of thermal analyses and FTIR; these phases are typical of alkaline activation processes in precursors with high calcium content, such as the KR slag used in this investigation; these compounds were not observed in the X-ray diffractograms due to their non-crystalline characteristics; iv) $\mathrm{CaCO}_{3}$ phase, identified in all analyses, was attributed to the carbonation of mixtures during the curing period; the $\mathrm{Ca}(\mathrm{OH})_{2}$ phase observed in XRD was a result of the hydration of $\mathrm{CaO}$ during the mixing process; the main unreacted phases were wüstite $(\mathrm{FeO})$ and iron magnesium oxide $\left(\mathrm{Fe}_{2} \mathrm{MgO}_{4}\right)$; v) overall, compound formation such as C-A-S-H and semi-crystalline $\mathrm{C}-\mathrm{S}-\mathrm{H}$ gel indicated the possibility of using KR steel slag to produce cementitious composites used in civil construction. However, more research is needed to improve knowledge about the alkaline activation process of KR slag.

\section{ACKNOWLEDGMENTS}

The authors are grateful for the experimental support of the following laboratories: Laboratory of Chemistry and Rheology of Asphalt Binders in UFC (Federal University of Ceará); LACAM Laboratory of Characterization of Materials; X-ray Laboratory; UFC Laboratory for Advanced Materials; UFC Laboratory for Civil Construction Materials; UFC Laboratory for Soil Analysis; and APODI Cement Company. The authors also acknowledge the support of Coordination for the Improvement of Higher Education Personnel (CAPES) and Pecém Steel Company (CSP).

\section{REFERENCES}

[1] P. Zhang, P.Y. Zheng, K. Wang, J. Zhang, Compos. B Eng. 152 (2018) 79.

[2] J.L. Provis, Mater. Struct. 47 (2014) 11.

[3] J.L. Provis, J.S.J. van Deventer (Eds.), “Alkali-activated materials", Report, RILEM TC 224-AAM, Springer (2014). [4] T. Luukkonen, Z. Abdollahnejad, J. Yliniemi, P. Kinnunem, M. Illikainen, Cem. Concr. Res. 103 (2018) 21. [5] J. Provis, J.S.J. van Daventer, Geopolymers: structure, processing, properties and industrial applications, Woodhead (2009).

[6] S.A. Bernal, J.L. Provis, A. Fernández-Jiménez, P.V. Krivenko, E. Kavalerova, Palacios, C. Shi, in "Alkaliactivated materials", J.L, Provis, J.S.J. van Deventer (Eds.), Report, RILEM TC 224-AAM, Springer (2014).

[7] B. Cho, H. Choi, Const. Build. Mater. 123 (2016) 436.

[8] Instituto Aço Brasil, "Relatório de sustentabilidade de 2016", Rio Janeiro (2016).

[9] Companhia Siderúrgica do Pecém, "Produtos", Pecém (2020).

[10] NBR 16605, "Portland cement and other powdered material: determination of the specific gravity", ABNT, Rio Janeiro (2017).

[11] T. Xie, P. Visitin, X. Zhao, R. Gravina, Constr. Build. Mater. 256 (2020) 119380.

[12] A. Naghizadeh, S.O. Ekolu, Constr. Build. Mater. 202 (2019) 704.

[13] Y.J. Zhang, L.C. Liu, Y. Xu, W.Y. Wang, D.L. Xu, J. Hazard. Mater. 146 (2012) 209.

[14] Z. Liu, D.W. Zhang, L. Li, J.X. Wang, N.N. Shao, D.M. Wang, Constr. Build. Mater. 204 (2019) 158

[15] N. Cristelo, J. Coelho, T. Miranda, A. Palomo, A. Fernandez-Jimenez, Cem. Concr. Compos. 103 (2019) 11. 
[16] M.N.S. Hadi, N.A. Farhan, M.N. Sheik, Constr. Build. Mater. 140 (2017) 424.

[17] N.G. Connie, U.J. Alengaram, L.S. Wong, M.O.K. Hung, M.Z. Jumaat, S.A. Ramesh, Constr. Build. Mater. 186 (2018) 550.

[18] W. Lokuge, A. Wilson, C. Gunasekara, D.W. Law, S. Setunge, Const. Build. Mater. 166 (2018) 472.

[19] I.B. Topçu, M.U. Toprak, T. Uygunoğlu, J. Clean. Prod. 81 (2014) 211.

[20] J. Zhang, S. Li, Z. Li, C. Liu, Y. Gao, J. Mater. Cycles Waste Manage. 22 (2020) 1328.

[21] Z. Sun, A. Vollpracht, Cem. Concr. Compos. 95 (2019) 98.

[22] J. Sun, Z. Chen, J. Therm. Anal. Calorim. 138 (2019) 47.

[23] NBR 9778, "Hardened mortar and concrete: determination of absorption, voids and specific gravity", ABNT, Rio Janeiro (2009).

[24] E.A. Langaro, "Cimento álcali ativado a partir da valorização da escória de alto forno a carvão vegetal”, M.Sc. Diss., Un. Tecn. Fed. Paraná, Curitiba (2016).

[25] A. Sathonsaowaphaka, P. Chindaprasirt, K. Pimraks, J. Hazard. Mater. 168 (2009) 44.

[26] M. Ben Haha, B. Lothenbach, G. Le Saout, F. Winnefeld, Cem. Concr. Res. 41 (2011) 955.

[27] S. Wang, K.L. Scrivener, Cem. Concr. Res. 25 (1995) 561.
[28] I. Nikolic, I. Karanovic, I.J. Castvan, V. Vuk Radmilovic, S.R. Mentus, V. Radmilovic, Mater. Lett. 133 (2014) 251. [29] M.L. Ben Haha, G. Le Saout, F. Winnwfel, B. Lothenbach, Cem. Concr. Res. 41 (2011) 301.

[30] B. Lothenbach, A. Gruskovnjak, Adv. Cem. Res. 2 (2007) 81.

[31] I. Ismail, S.A. Bernal, J.L. Provis, R.S. Nicolas, S. Hamdan, J.S.J. van Deventer, Cem. Concr. Compos. 45 (2014) 125.

[32] D. Ravikumar, N. Neithalath, Cem. Concr. Compos. 34 (2012) 809 .

[33] K.H. Aziz, K. Zulkifly, K. Sakkas, D. Panias, G.M. Tsaousi, M.M.A.A. Bakril, H.C. Yong, OALib 4 (2017) 3816.

[34] I. Garcia-Lodeiro, A.E.M. Fernandez-Jimenez, T. Blanco, A. Palomo, J. Sol-Gel Sci. Technol. 45 (2008) 63.

[35] S. Kumar, R. Kumar, Ceram. Int. 37 (2011) 533.

[36] A.S. Vargas, "Cinzas volantes álcali-ativadas para obtenção de aglomerantes especiais", Doct. Thesis, Un. Fed. Rio Grande Sul, Porto Alegre (2006).

[37] M. Criado, W. Aperador, I. Sobrados, I. Col, Raw Mater. 9 (2016) 158.

[38] F. Puertas, M. Palacios, H. Manzano, J.S. Dolado, A. Rico, J. Rodrigues, J. Eur. Ceram. Soc. 31 (2011) 2043. (Rec.07/09/2020, Rev. 14/12/2020, 23/04/2021, 19/05/2021, Ac. 24/05/2021) 